\title{
Not all that clear cut: intraspecific morphological variability in Squalus blainville (Risso, 1827) and implications for identification of the species
}

\author{
JUAN JOSÉ BONELLO ${ }^{1}$, LEANNE BONNICI ${ }^{1}$, ALICE FERRARI ${ }^{2}$, ALESSIA CARIANI ${ }^{2}$ \\ AND PATRICK J. SCHEMBRI ${ }^{1}$ \\ ${ }^{1}$ Department of Biology, University of Malta, Msida MSD2080, Malta, ${ }^{2}$ Department of Biological, Geological \& Environmental \\ Sciences (BiGeA), University of Bologna, via Selmi 3, 40126 Bologna, Italy
}

\begin{abstract}
Of the three species of the genus Squalus that occur in the Mediterranean Sea, S. blainville and S. megalops are very difficult to distinguish. This study assesses the variability in morphological features that have been used to differentiate between these species. Squalus were collected from stations within the 25-nautical mile Fisheries Management Zone around the Maltese Islands; 349 specimens were dissected and categorized into male and female, mature and immature, and individuals were randomly selected from each category to make up a sample of 169 specimens. For each individual, total length and first dorsal fin parameters were measured, and morphology of denticles isolated from the laterodorsal area, of the upper and lower teeth and of the chondrocranium was analysed. The first dorsal spine was shorter that the fin base in 93\% of the specimens, which is typical of S. megalops; this character was not related to either gender or maturity. Chondrocrania with one lateral process (typical of S. blainville) and two lateral processes (typical of S. megalops) were present. Teeth from the same individuals showed morphological features that overlap between S. blainville and S. megalops. Both unicuspid (typical of S. megalops) and tricuspid denticles (typical of S. blainville) were observed on the same individuals. Twelve specimens (six having one and six having two lateral chondrocranial processes) were analysed genetically by sequencing of the mtDNA marker Cytochrome Oxidase Subunit I (COI). All resulted to be S. blainville showing that intraspecific variability in supposedly diagnostic morphological features is large enough to render these unreliable to tell apart these two species, especially in the field.
\end{abstract}

Keywords: Squalus megalops, Squalus blainville, Mediterranean Sea, Malta, identification, taxonomy, morphology, genetic analysis

Submitted 9 June 2015; accepted 28 October 2015

INTRDDUCTION

The taxonomy of some species within the genus Squalus is confused as several nominal species have been described without an extensive comparison with the types of previously instituted taxa (Muñoz-Chápuli \& Ramos, 1989). Additionally, there is a lack of assessment of the variation within species, resulting in a complex list of synonyms and frequent misidentifications. For these reasons, the genus Squalus is considered to be one of the most taxonomically problematic shark groups (Bigelow \& Schroeder, 1957; Garrick, 1960, 1961; Muñoz-Chápuli \& Ramos, 1989; Last et al., 2007; White et al., 2007; Ebert \& Stehman, 2013), as exemplified by the number of species assigned to the genus, which varies between nine (Compagno, 1984) and the most recently proposed 27 (Ebert \& Stehman, 2013).

Three species of Squalus are presently known from the Mediterranean Sea: Squalus acanthias Linnaeus, 1758, Squalus blainville (Risso, 1826) and Squalus megalops

Corresponding author:

J.J. Bonello

Email: juanjbonello@gmail.com
(Macleay, 1881) (Muñoz-Chápuli \& Ramos, 1989; Serena, 2005; Ragonese et al., 2013), of which S. blainville and S. megalops may actually represent species complexes (Ebert \& Stehman, 2013). Although S. acanthias is often confused with S. blainville, the body and eye colour, and the presence of white spots on the back of the former are considered distinctive features, as is the shape of the pectoral fin, which in $S$. acanthias has narrowly round to acutely angular rear tips and inner margins (Bigelow \& Schroeder, 1957; Compagno, 1984). On the other hand, the main feature that distinguishes S. blainville from the species of the S. megalops - S. cubensis group is the shape of the pectoral fin corner, which is rounded in the former and pointed in the latter. However, some variation has been observed, and occasionally $S$. blainville shows a pectoral fin outline like S. megalops (Bigelow \& Schroeder, 1957; Muñoz-Chápuli \& Ramos, 1989). Due to the rather minor morphological differences between S. blainville and S. megalops, these two have often been considered as a single species. However, S. megalops appears to be a species complex with a very wide range that spans the Eastern Atlantic and Indo-West Pacific, making differentiation between S. blainville and S. megalops even more difficult (Serena, 2005; Ebert \& Stehman, 2013). 
According to the detailed study by Marouani et al. (2012), more or less clear-cut characters that differentiate between these two problematic species are the flank denticles, teeth and the number of cartilaginous processes on each side of the basal plate of the chondrocranium (Table 1). Despite detailed morphological comparisons of $S$. blainville and $S$. megalops, there is still much uncertainty as to what exactly constitutes S. blainville. As has been pointed out many times (Chen et al., 1979; Muñoz-Chápuli \& Ramos, 1989) the original description of S. blainville by Risso (1826) is insufficient and there are no extant types, leading to speculation and problems in the use of the name S. blainville (Last et al., 2007). The type locality of Risso's species is the Mediterranean but no Mediterranean shark conforms to Risso's description (Chen et al., 1979; Muñoz-Chápuli \& Ramos, 1989). This has resulted in the use of this name for a number of species even outside the Mediterranean (Chen et al., 1979; Abiadh et al., 2010); details of the biology of this shark are uncertain because of such taxonomic problems (Ebert \& Stehman, 2013).
These taxonomic problems present obstacles to researchers and to fisheries and conservation managers (Last et al., 2007; Ebert \& Stehman, 2013). Catch data are unreliable as S. blainville is frequently taken as part of mixed catches and it is not usually sorted out and reported on separately from its congeners. The conservation status of both S. blainville and S. megalops is currently considered to be 'Data Deficient' due to taxonomic uncertainty (Serena, 2005; Ebert et al., 2010; Ebert \& Stehman, 2013; Nieto et al., 2015). In the Mediterranean, S. blainville is considered to be common and is sold in local markets; landings of S. blainville reportedly represent about $3 \%$ of the mean total biomass of elasmobranchs caught in fisheries (Ragonese et al., 2013). However, while Ragonese et al. (2013) argue that S. megalops is in fact rare, other studies contradict this and state that $S$. megalops is more common than S. blainville (Bradai et al., 2012).

The present report owes its origin to a study on the feeding preferences of $S$. blainville based on a large collection of specimens originally collected for fisheries statistics purposes. In confirming the identification of the individual fish, the

Table 1. The main morphological characteristics which distinguish S. blainville and S. megalops, based on Garrick (1960, 1961); Chen et al. (1979); Compagno (1984); Muñoz-Chápuli \& Ramos (1989); Marouani et al. (2012); Ebert \& Stehman (2013); FAO (2015).

\begin{tabular}{|c|c|c|c|}
\hline Species & & Squalus blainville (Risso, 1827) & Squalus megalops (Macleay, 1881) \\
\hline Type location & & $\begin{array}{l}\text { Risso, 1826, Hist. nat. Princip. prod. Europe Méréd., } \\
\text { Paris, Poissons, 3:133, pl. 3, Figure 6. Plate legend, } \\
\text { p. 478, has variant spelling Acanthias blainvillii, } \\
\text { used by many subsequent writers. Holotype } \\
\text { Unknown. Type locality: off Nice, France, } \\
\text { Mediterranean Sea }\end{array}$ & $\begin{array}{l}\text { Macleay, } 1881 \text {, Rec. Australian Mus., 4:33, pl. 4, } \\
\text { Figure 2. Holotype: Australian Museum, Sydney. } \\
\text { Type locality: Port Jackson, Australia }\end{array}$ \\
\hline Range of distribution & & $\begin{array}{l}\text { Eastern Atlantic: Bay of Biscay to Mediterranean, } \\
\text { Morocco, Canaries, Senegal to Namibia (may } \\
\text { include other species in addition to S. blainville). } \\
\text { Western Pacific: southern Japan and Taiwan } \\
\text { Island. Nominal records of S. blainville or S. } \\
\text { fernandinus from the western Atlantic (northern } \\
\text { Carolina to northern Gulf of Mexico (USA); } \\
\text { Argentina), Indian Ocean (South Africa, } \\
\text { Mozambique, Madagascar, Tanzania and India), } \\
\text { western Pacific (Australia, New Zealand, New } \\
\text { Caledonia), central Pacific (Hawaiian Islands), and } \\
\text { eastern Pacific (northern Chile), as well as some } \\
\text { records from the western North Pacific and eastern } \\
\text { Atlantic, are based at least in part on S. mitsukurii } \\
\text { and possibly other species. Whether S. blainville } \\
\text { itself is as wide-ranging as reported for the } \\
\text { blainville-group dogfishes (including S. mitsukurii) } \\
\text { remains to be determined }\end{array}$ & $\begin{array}{l}\text { Eastern Atlantic and western Indian Ocean: } \\
\text { Guinea, Gabon to Namibia, South Africa, } \\
\text { Mozambique. Western Pacific: Japan, the Koreas, } \\
\text { China, Viet Nam; Australia (South Australia, } \\
\text { Victoria, Tasmania), New Caledonia and New } \\
\text { Hebrides }\end{array}$ \\
\hline \multirow{6}{*}{$\begin{array}{l}\text { Characteristics } \\
\text { considered in this } \\
\text { study }\end{array}$} & Pectoral fin & Rounded pectoral free rear tip. & Angular pectoral free rear tip. \\
\hline & Preoral snout tip & $\begin{array}{l}\text { Snout tip to inner margin of the nostril longer than } \\
\text { the distance from the inner edge of nostril to the } \\
\text { front of the upper labial furrow }\end{array}$ & $\begin{array}{l}\text { Shorter distance from snout tip to inner margin of } \\
\text { the nostril }\end{array}$ \\
\hline & Dorsal fin & $\begin{array}{l}\text { First dorsal fin height over } 3 / 4 \text { of the length of the fin } \\
\text { from origin to base }\end{array}$ & Moderately high first dorsal fin, about half its length \\
\hline & Denticles & Tricuspidate lateral denticles & Denticles small, lanceolate and unicuspidate \\
\hline & Teeth & $\begin{array}{l}\text { Teeth are similar in both jaws, small, compressed, } \\
\text { with a single cusp deeply notched and outward end } \\
\text { strongly oblique }\end{array}$ & $\begin{array}{l}\text { Teeth are similar in upper and lower jaws, with the } \\
\text { lower teeth unicuspid, elongated, interlocking } \\
\text { and the cusps directed strongly laterally }\end{array}$ \\
\hline & $\begin{array}{l}\text { Cartilaginous } \\
\text { processes }\end{array}$ & $\begin{array}{l}\text { One on each side of the basal plate of the } \\
\text { chondrocranium }\end{array}$ & $\begin{array}{l}\text { Two on each side of the basal plate of the } \\
\text { chondrocranium }\end{array}$ \\
\hline
\end{tabular}


authors came across specimens that were ambiguous to assign to either S. blainville or S. megalops based on morphological characters given in field guides. An attempt was made to identify these specimens based on detailed examination of multiple characters, including internal ones. However, it still proved difficult to distinguish between $S$. megalops and S. blainville due to the degree of variability of key features that supposedly differentiate between the two. The question was ultimately resolved through genetic analysis, DNA barcoding having been shown to be a powerful tool in distinguishing between different species of squalids, although very few studies have been made on S. blainville or S. megalops (Ward et al., 2007; Marouani et al., 2012; Landi et al., 2014).

Here we report on the variability within the sample of $S$. blainville studied, since this variability has an important bearing on the accuracy of identification of the species, and therefore may affect the quality of data collected on Mediterranean species of Squalus.

\section{METHDDOLDGY}

\section{Collection of specimens}

Samples were collected from stations within the 25-nautical mile Fisheries Management Zone (FMZ) around the Maltese Islands, which is included in FAO's General Fisheries Commission for the Mediterranean (GFCM) Geographical Sub-Area 15 (GSA 15). The specimens were collected either by bottom long-liners or by commercial otter trawlers.

The samples were collected from commercial fishing vessels. For operational reasons, trawling was undertaken both during the day and night.

Hauls were of 30-60 min duration, except in deep water when they were of $4 \mathrm{~h}$.

In all cases, the nets used were the 'Mazara' type otter trawls adjusted according to the type of terrain on which operations were being conducted (Fisheries Control Directorate, 2013).

The bottom set long-lines were usually set in deep rocky areas at depths of around $200 \mathrm{~m}$ near the shelf break.

\section{Morphological studies}

A total of 349 specimens were measured and dissected, of which a sample of 169 specimens was used for this study. This sample was chosen by first categorizing the total available specimens as males and females, and, within each, as mature and immature, and then selecting individuals at random from each category. Parameters considered for differentiating between Squalus species were selected from the characters used by various authors (Bigelow \& Schroeder, 1957; Compagno, 1984; Muñoz-Chápuli \& Ramos, 1989; Last et al., 2007; Marouani et al., 2012).

The total length and the first dorsal fin parameters (Figure 1) were measured to the closest $1 \mathrm{~mm}$; the weight was measured to the closest $10 \mathrm{~g}$; sex was based on the presence or absence of claspers and the maturity stage was determined according to the classification given in the MEDITS Handbook (MEDITS, 2013). For analysis, individuals were categorized either as immature (corresponding to Stage 1-2 from Plate VIIIC, MEDITS, 2013) or mature (individuals capable of reproduction, actively spawning, maternal,

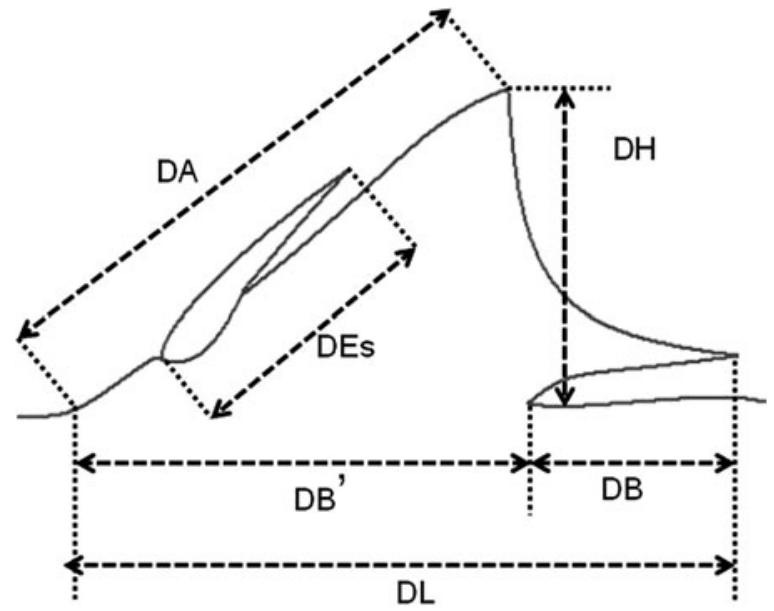

Fig. 1. Measurements taken from the first dorsal fin: DL (dorsal length), DB (dorsal base length), DB' (attached dorsal base length), DH (dorsal height), DA (dorsal anterior margin) and DEs (dorsal spine length). Nomenclature adapted from Last et al. (2007) and Marouani et al. (2012).

regressing and regenerating, corresponding to Stage 3-4 from Plate VIIIC, MEDITS, 2013).

The denticles were observed using a Nikon SMZ 1500 stereomicroscope. The skin samples were obtained from the laterodorsal area, under the first dorsal fin and just above the pectoral fin.

\section{Chondrocranial measurements}

Heads were macerated according to the techniques described by Knudsen (1966) and Hildebrand (1968), with some minor modifications; for those skulls that were not fully macerated after $10-12 \mathrm{~h}$, the macerating solution $(25 \mathrm{~mL}$ of $35 \%$ hydrochloric acid diluted in $200 \mathrm{~mL}$ distilled water) was replaced and left to act for a further 10-12 h. Afterwards, the skull was neutralized for $20 \mathrm{~min}$ in $2.5 \%$ ammonia solution.

Chondrocranial measurements and nomenclature, with some minor modifications, follow Muñoz-Chápuli \& Ramos (1989) and Marouani et al. (2012) (Figure 2). Chondrocranial measurements were expressed as a percentage of the total length of the chondrocranium.

The first dorsal fin measurements and the chondrocranial measurements were compared using Student's $t$-test and the Mann-Whitney $U$-test, implemented using IBM SPSS Statistics 20.0 software (IBM Corp., Armonk, NY, USA, 2011).

\section{Teeth morphometric analysis}

The upper and lower jaws were treated with $2 \mathrm{M}$ potassium hydroxide for $12 \mathrm{~h}$, in order to separate the teeth from the jaws.

The teeth were photographed with a DS-Ri1 camera attached to a Nikon SMZ 1500 stereomicroscope.

The classification of teeth based on the shape is somewhat subjective; therefore morphometric techniques were used to objectively quantify the curvature at the periphery of each tooth (Bookstein, 1997; Kendall, 1977; Farré et al., 2013).

The program MorphoJ (Klingenberg, 2011) was used to analyse shape changes described by principal components analysis (PCA) (following the procedure of Ferdous \& 

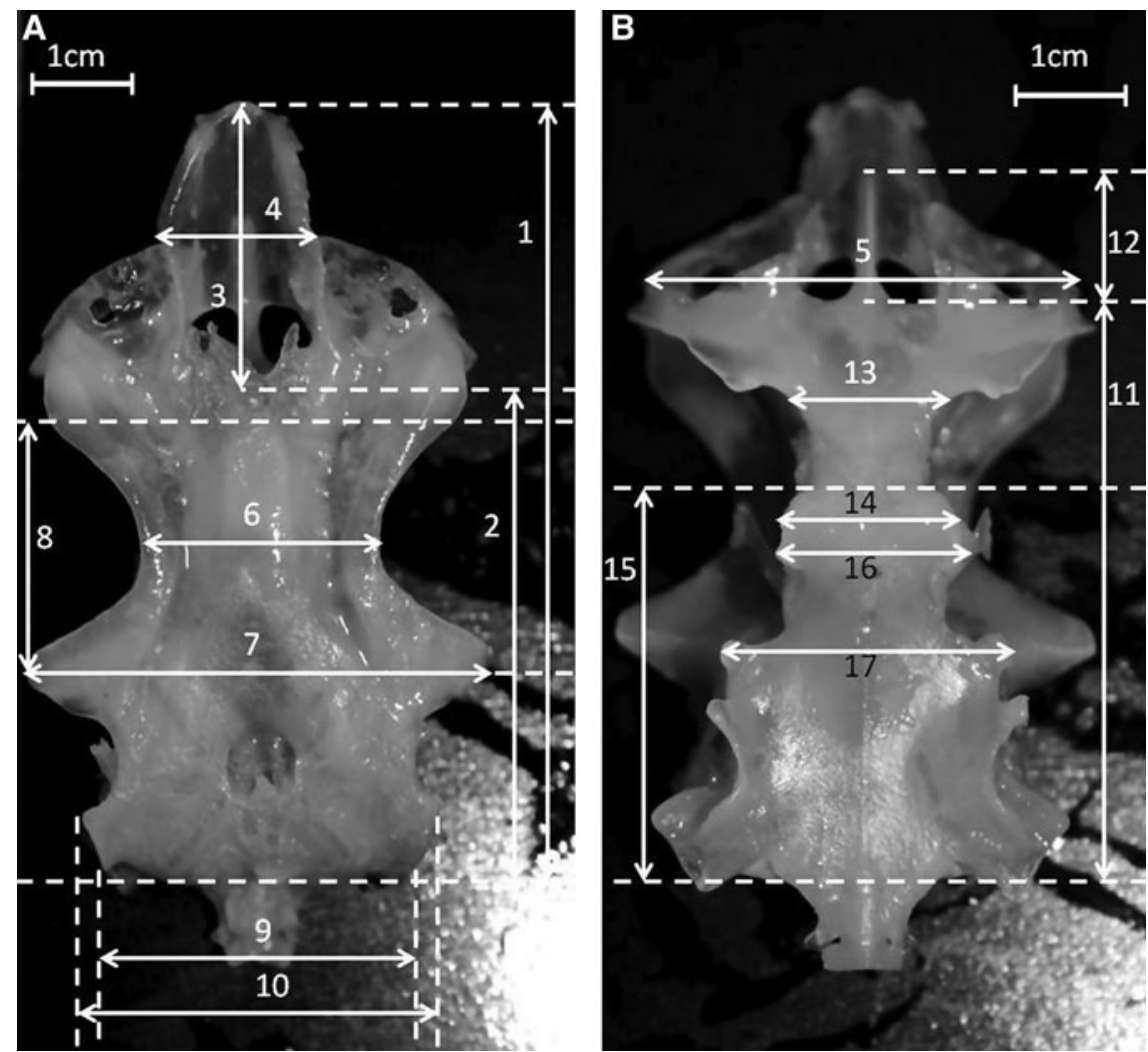

Fig. 2. Chondrocranium of Squalus in (A) dorsal and (B) ventral view showing the measurements taken. (1) Total length of chondrocranium; (2) posterior tip-precerebral fenestra; (3) length precerebral fenestra; (4)width precerebral fenestra; (5) width across nasal capsules; (6) interorbital width; (7) postorbital width; (8) distance between orbital processes; (9) width between pterotic processes; (10) width between pterotic processes; (11) posterior tip-rostral keel; (12) length rostral keel; (13) subethmoidean width; (14) width basal angle; (15) length basal plate; (16) width anterior basal plate A; (17) width anterior basal plate B. The nomenclature is adapted from Muñoz-Chápuli \& Ramos (1989).

Armbruster 2012) using both landmarks and semi-landmarks (Kendall, 1977; Bookstein, 1997; Farré et al., 2013).

Following the work of Lo Brutto et al. (2013), the semilandmarks were constrained to retain the position on the outline curve of the tooth (Figure 3 ). Once the optimally

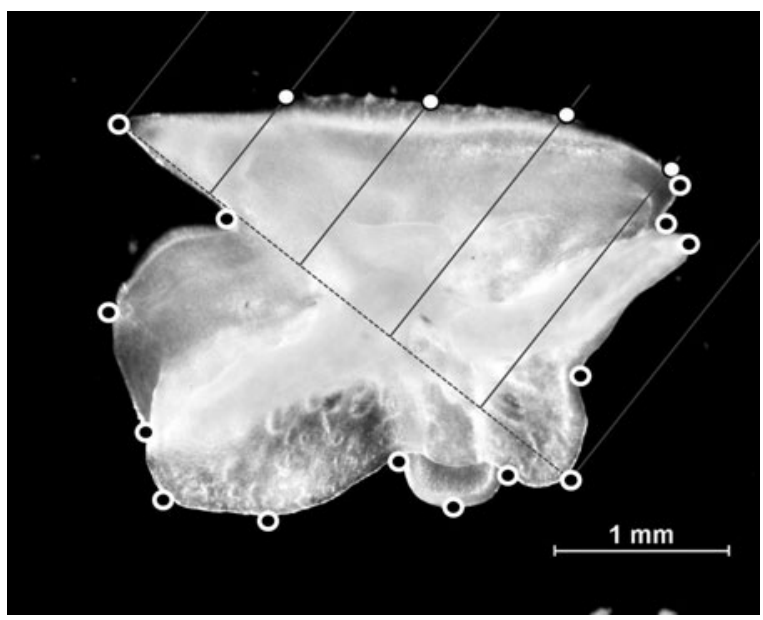

Fig. 3. The location of the landmarks (black points + white outline) on the upper tooth of a mature male specimen. A scale (solid lines) divided in equal intervals was constructed by drawing a line (dotted line) from the two extremes of the tooth; semi-landmarks (white points + black outline) were then the points of intersection of the scale with the tooth edge. A total of 14 landmarks and 4 semi-landmarks were determined for each tooth. adjusted positions of the landmarks and semi-landmarks were determined, they were treated in the same way in the subsequent statistical analyses.

From each specimen, a sample of four teeth from the upper rows and four teeth from the lower rows were considered, thus a total of eight teeth from each individual were analysed. In order to carry out the statistical analysis, the mean measurements for the upper teeth and the mean measurements for the lower teeth were used.

\section{Genetic analysis}

A subsample of 12 specimens was used for genetic analysis; six specimens were selected from those with a chondrocranium with a single lateral process of the basal plate and the other six from individuals with a double lateral process of the basal plate; according to Marouani et al. (2012) the former is characteristic of $S$. blainville while the latter is characteristic of $S$. megalops.

Total genomic DNA (gDNA) was extracted from muscle tissue stored in $96 \%$ ethanol, following the cetyltrimethyl ammonium bromide (CTAB) protocol (Doyle \& Doyle, 1987). The $5^{\prime}$-end of COI gene (about $650 \mathrm{bp}$ ) was amplified with the FishF2/R2 primers (Ward et al., 2005). PCR reactions were performed in $50 \mu \mathrm{L}$ of total volume, containing about $20 \mathrm{ng}$ of DNA template, $1 \times$ PCR buffer, $3 \mathrm{mM} \mathrm{MgCl}_{2}$, $0.1 \mathrm{mM}$ of each dNTP, $1.0 \mu \mathrm{M}$ of each primer, and 1 unit of Taq DNA polymerase (all reagents from Promega). 
Table 2. Summary of the retrieved sequences for S. blainville, S. megalops and S. acanthias from BOLD and NCBI databases. The number of sequences is reported for each species and per FAO Division.

\begin{tabular}{|c|c|c|c|c|c|c|c|}
\hline Species & $\begin{array}{c}\text { Sardinia } \\
\text { (division } \\
\text { 37.1.3) }\end{array}$ & $\begin{array}{c}\text { Adriatic } \\
\text { (division } \\
\text { 37.2.1) }\end{array}$ & $\begin{array}{c}\text { Ionian } \\
\text { (division.37.2.2) }\end{array}$ & $\begin{array}{l}\text { Levant } \\
\text { (division } \\
\text { 37.3.2) }\end{array}$ & $\begin{array}{c}\text { Southwest } \\
\text { Australia } \\
\text { (division 57.5.2) }\end{array}$ & $\begin{array}{c}\text { Southern } \\
\text { Australia } \\
\text { (subarea 57.6) }\end{array}$ & $\begin{array}{c}\text { Total } \\
\text { sequences per } \\
\text { species }\end{array}$ \\
\hline Squalus acanthias & o & 134 & o & 0 & o & o & 134 \\
\hline Squalus blainville & 10 & 0 & 9 & 5 & o & o & 24 \\
\hline Squalus megalops & 0 & 0 & o & o & 4 & 5 & 9 \\
\hline $\begin{array}{l}\text { Total sequences per } \\
\text { FAO division }\end{array}$ & 10 & 134 & 9 & 5 & 4 & 5 & 167 \\
\hline
\end{tabular}

The following PCR cycling conditions were used: initial denaturation for $2 \mathrm{~min}$ at $94^{\circ} \mathrm{C}, 30$ cycles for $30 \mathrm{~s}$ at $94^{\circ} \mathrm{C}$, $30 \mathrm{~s}$ at $56^{\circ} \mathrm{C}, 1 \mathrm{~min}$ at $72^{\circ} \mathrm{C}$ and a final extension for $7 \mathrm{~min}$ at $72^{\circ} \mathrm{C}$. PCR fragments obtained were visualized on $1.5 \%$ agarose gels. PCR products were stored at $-20^{\circ} \mathrm{C}$ until they were shipped to Macrogen Europe (Amsterdam, the Netherlands) for purification and sequencing.

The electropherograms were manually edited for all forward sequences, as well as for reverse ones when available, and the final sequences were aligned using the ClustalW algorithm (Thompson et al., 1994), analysed with MEGA 6 software (Tamura et al., 2013) and the correct amino acidic translation was assessed to exclude nuclear mitochondrial pseudogenes (Song et al., 2008).
All input consensus sequences were firstly compared with published sequences from BOLD systems (http://www.bold systems.org/) and NCBI databases through the BLAST algorithm (http://blast.ncbi.nlm.nih.gov/Blast.cgi) and all specimens were correctly identified as Squaliformes, to rule out any errors due to mishandling of samples during laboratory processing.

Available sequences were retrieved for $S$. blainville, S. megalops and S. acanthias, from both databases. When possible, retrieved data had different geographic origin to properly assess intraspecific species diversity (Table 2). The retrieved sequences were merged with those for the Maltese Squalus specimens, the intra and inter-specific genetic distances were calculated and a Neighbour-joining (NJ) tree (Saitou \& Nei,

Table 3. First dorsal fin measurements of Squalus samples and comparisons using the Mann-Whitney $U$-test $\left({ }^{*} P<0.05\right.$; bold values: statistically different).

\begin{tabular}{|c|c|c|c|c|c|c|c|c|c|}
\hline & \multicolumn{3}{|c|}{ Gender } & \multicolumn{3}{|c|}{ Lateral process of the basal plat } & \multicolumn{3}{|c|}{ Maturity } \\
\hline & $\begin{array}{l}\text { Female } \\
N=90\end{array}$ & $\begin{array}{c}\text { Males } \\
\mathrm{N}=79\end{array}$ & \multirow{2}{*}{$\begin{array}{c}\text { Mann- } \\
\text { Whitney } \\
\text { Asymp. Sig. } \\
\text { (2-tailed) }\end{array}$} & $\begin{array}{c}1 \text { lobed } \\
(\mathrm{N}=23)\end{array}$ & $\begin{array}{c}2 \text { lobed } \\
(\mathrm{N}=146)\end{array}$ & \multirow{2}{*}{$\begin{array}{c}\text { Mann- } \\
\text { Whitney } \\
\text { Asymp. Sig. } \\
\text { (2-tailed) }\end{array}$} & $\begin{array}{c}\text { Immature } \\
(\mathrm{N}=77)\end{array}$ & $\begin{array}{l}\text { Mature } \\
(\mathrm{N}=92)\end{array}$ & \multirow{2}{*}{$\begin{array}{c}\text { Mann - } \\
\text { Whitney } \\
\text { Asymp. Sig. } \\
\text { (2-tailed) }\end{array}$} \\
\hline & \multicolumn{2}{|c|}{ Mean \pm SD } & & \multicolumn{2}{|c|}{ Mean $\pm S D$} & & \multicolumn{2}{|c|}{ Mean \pm SD } & \\
\hline DL & $13.05 \pm 1.26$ & $12.99 \pm 0.90$ & 0.512 & $13.13 \pm 1.20$ & $13.00 \pm 1.09$ & 0.967 & $12.89 \pm 1.29$ & $13.13 \pm 0.92$ & 0.171 \\
\hline $\mathrm{DH}$ & $8.09 \pm 1.37$ & $8.20 \pm 1.19$ & 0.305 & $8.30 \pm 2.08$ & $8.12 \pm 1.12$ & 0.458 & $8.71 \pm 1.42$ & $7.67 \pm 0.93$ & $<0.001^{*}$ \\
\hline DA & $10.99 \pm 1.17$ & $10.66 \pm 1.16$ & 0.050 & $10.80 \pm 1.78$ & $10.84 \pm 1.06$ & 0.863 & $11.01 \pm 1.26$ & $10.69 \pm 1.08$ & $0.025^{*}$ \\
\hline DEs & $4.69 \pm 0.92$ & $4.69 \pm 1.52$ & 0.237 & $4.98 \pm 1.73$ & $4.65 \pm 1.13$ & 0.110 & $4.64 \pm 1.21$ & $4.73 \pm 1.23$ & 0.588 \\
\hline DB & $6.11 \pm 0.93$ & $5.88 \pm 1.07$ & 0.217 & $6.08 \pm 0.93$ & $5.99 \pm 1.01$ & 0.760 & $6.20 \pm 1.24$ & $5.83 \pm 0.71$ & $0.001^{*}$ \\
\hline DB' & $7.01 \pm 1.11$ & $7.12 \pm 1.12$ & 0.375 & $7.05 \pm 0.96$ & $7.06 \pm 1.13$ & 0.721 & $6.78 \pm 1.20$ & $7.30 \pm 0.97$ & $0.001^{*}$ \\
\hline
\end{tabular}
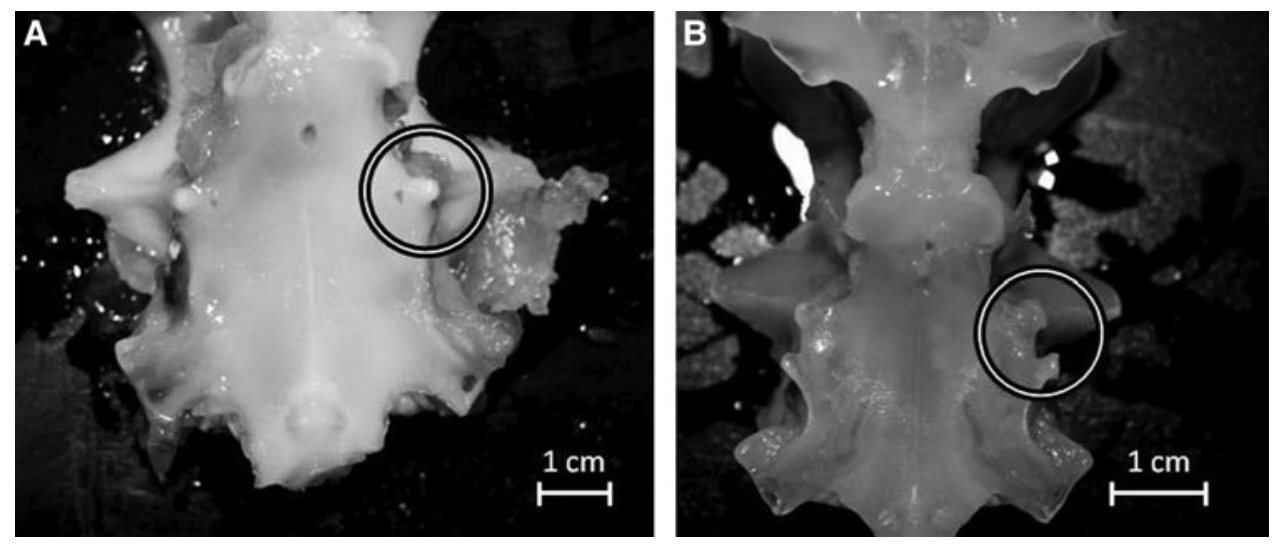

Fig. 4. The different lateral process of the basal plate, (A) a single lateral process of the basal plate as observed in a mature female and (B) a double lateral process of the basal plate as observed in an immature female. 
1987) was obtained selecting the p-distance model and 'pairwise deletion' option for the treatment of gaps and missing data. A bootstrap test with 1000 replicates (Felsenstein, 1985) was performed to evaluate the robustness of this reconstruction. Oxynotus centrina (L.) (BOLD Process ID ELAME112$09 \mid$ GU805137) was chosen as an out-group for the analysis.

\section{RESULTS}

\section{External features}

In this study, $93 \%$ of the specimens $(\mathrm{N}=169)$ had the first dorsal spine shorter than the fin base, which is a characteristic of $S$. megalops, while the rest had the first dorsal spine longer than the fin base, which is a characteristic of S. blainville according to the literature (Chen et al., 1979; Serena, 2005; Marouani et al., 2012). Table 3 shows that even though a number of parameters associated with the first dorsal spine are significantly different in juveniles compared with mature individuals, there is no significant difference in dorsal spine length (DEs).

Therefore, the difference in the length of the first dorsal spine and the fin base ratio in the studied individuals cannot be attributed to either gender or maturity differences.

\section{Chondrocranial measurements}

A total of 349 skulls were dissected and macerated; 25 of these were characterized by a single lateral process of the basal plate (Figure 4A), which, according to Marouani et al. (2012), is characteristic of $S$. blainville. The remaining specimens had a double lateral process of the basal plate (Figure $4 \mathrm{~B}$ ), which is characteristic of $S$. megalops (Marouani et al., 2012).

The chondrocranial measurements are shown in Table 4. Individual chondrocranial features were significantly different between males and females and between juvenile and mature individuals, however, there were no overall consistent differences attributable to gender or maturity.

\section{Morphometric analysis}

Visual observation of the teeth showed that in some cases, different teeth from the same specimen sometimes fitted the description of the teeth of both S. blainville and S. megalops (Compagno, 1984; Marouani et al., 2012; Ebert \& Stehman, 2013). This means that in the same individual, teeth which were deeply notched and had the outward end strongly oblique, normally associated with $S$. blainville, were present with others that were elongated, interlocking and had the cusps directed strongly laterally, normally used to identify $S$. megalops.

The PCA showed clearly that when considering the lower teeth, two distinctive clusters were observed which were, however, not related to sex, maturity and the number of lobes (Figure 5). A similar pattern was observed for the upper teeth.

\section{Denticles}

Both tricuspid and unicuspid denticles were found on the same individual; the tricuspid denticles were observed just

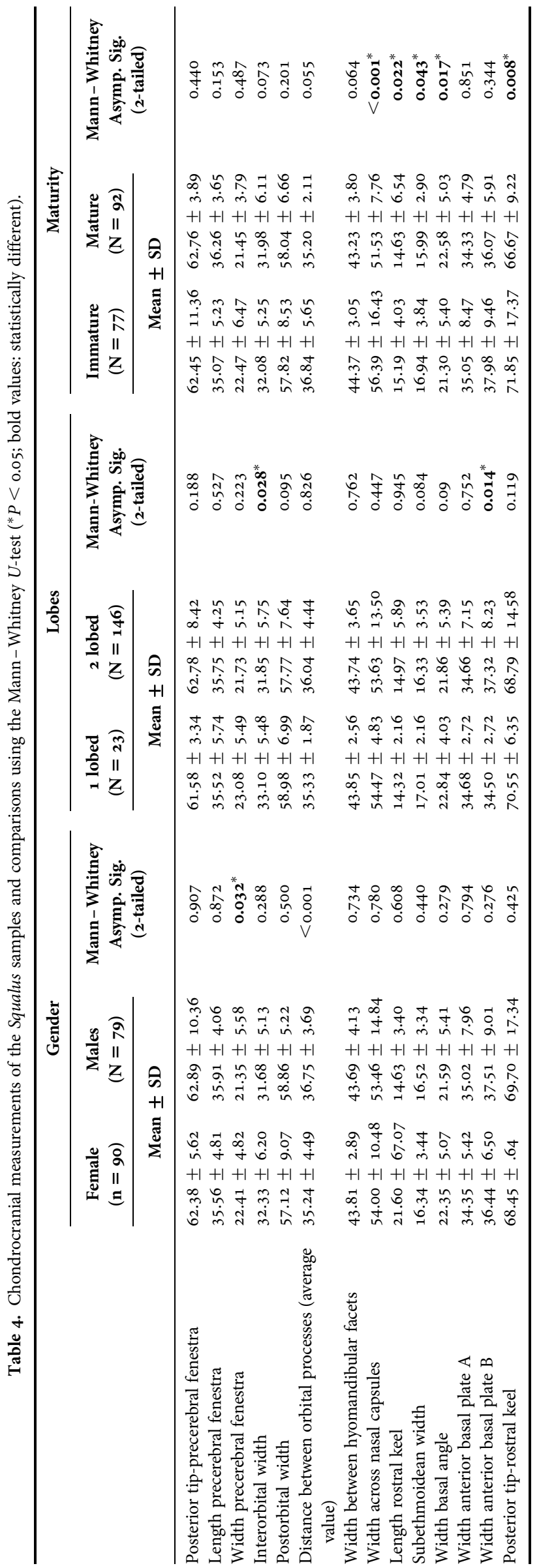


A
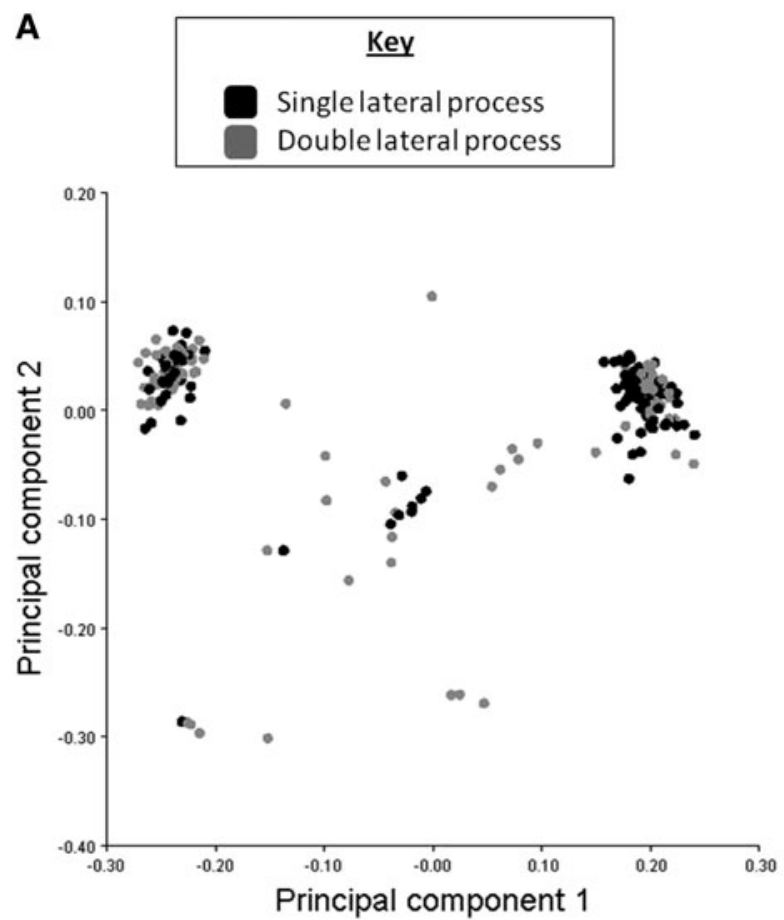

B
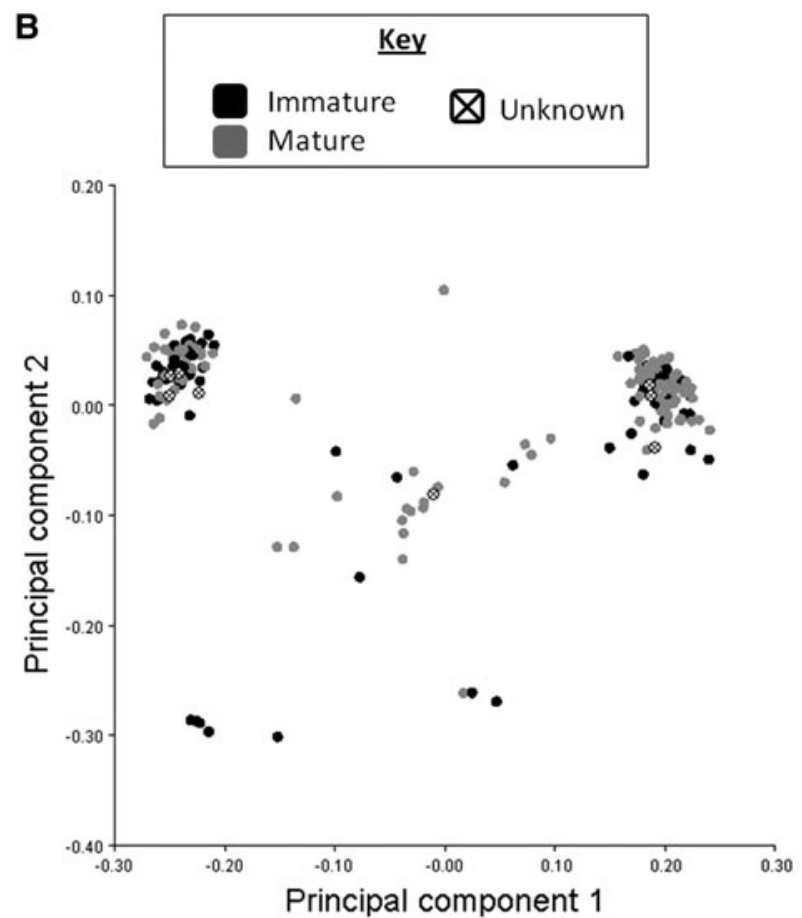

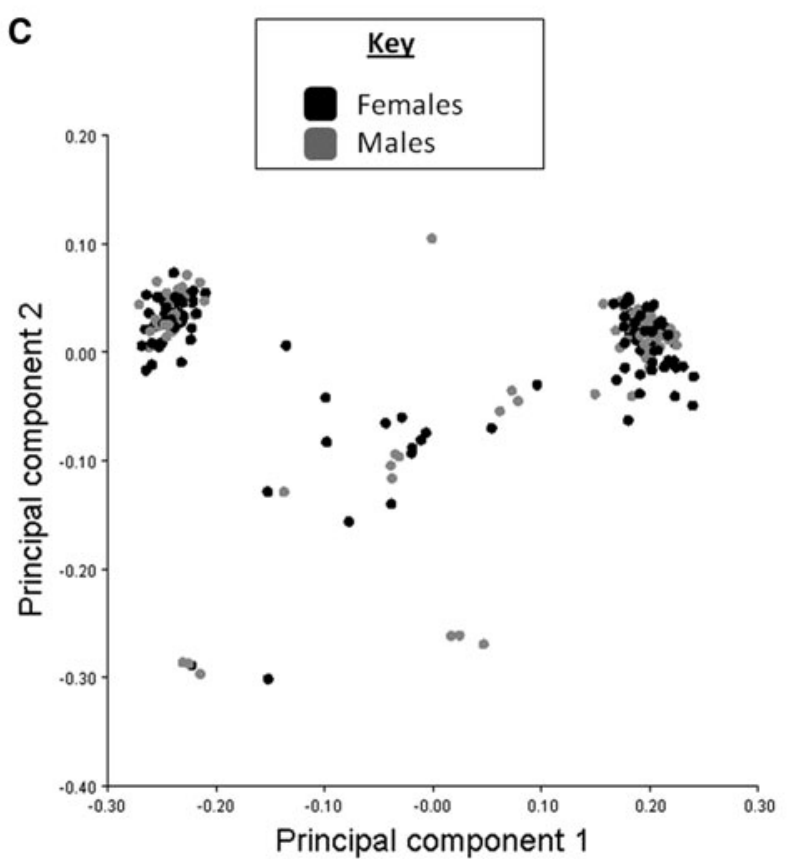

Fig. 5. Principal component analysis of each individual lower teeth. The data points were classified according to (A) the number of lateral process of the basal plate of the skull (single/double); (B) maturity (immature/mature) and (C) sex (males/females).

under the first dorsal fin and the unicuspid ones just above the pectoral fin (Figure 6).

\section{Genetic analysis}

Total gDNA was extracted from 12 individuals, but only eight of them were successfully COI-amplified and sequenced. Amino acid translation showed no stop codons and the BLAST search confirmed their assignment to the genus Squalus.
A total of 167 sequences were retrieved from BOLD database (134 for S. acanthias, 24 for S. blainville and nine for S. megalops) and added to the eight newly obtained sequences. The final dataset for downstream analyses consisted of 176 sequences (of $652 \mathrm{bp}$ ), where each individual was identified with the corresponding BOLD Process ID.

The reconstructed NJ topology shown in Figure 7 clearly demonstrated that the eight newly obtained sequences of Maltese Squalus clustered among S. blainville individuals in a scattered pattern and revealed a remarkable genetic differentiation within this taxon. On the other hand, both S. megalops 


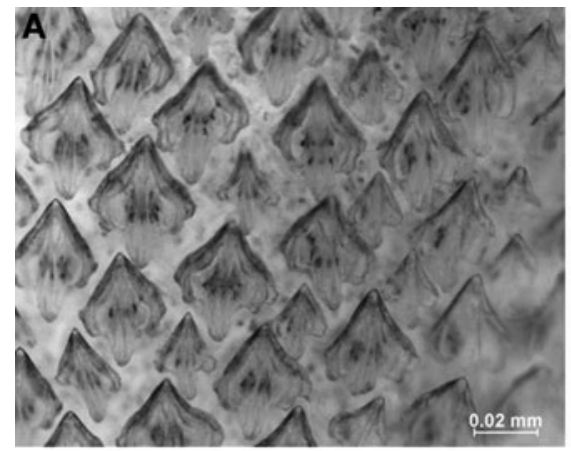

B1-0002_Dorsal fin

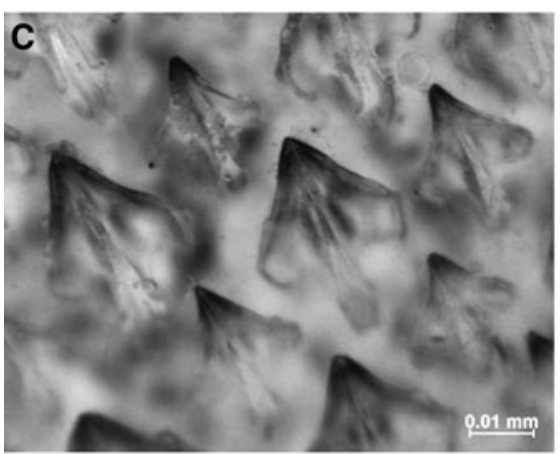

B16-0093_Dorsal fin

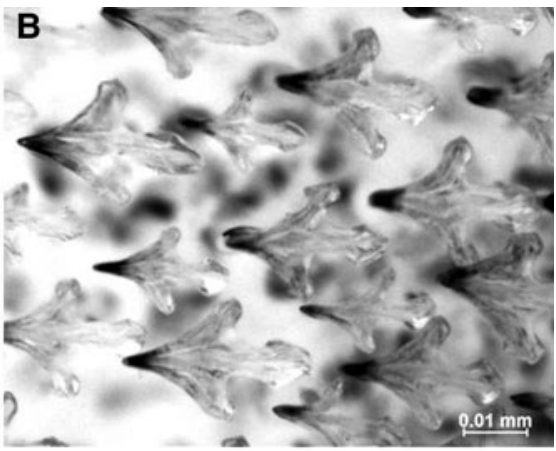

B1-0002_Pectoral fin

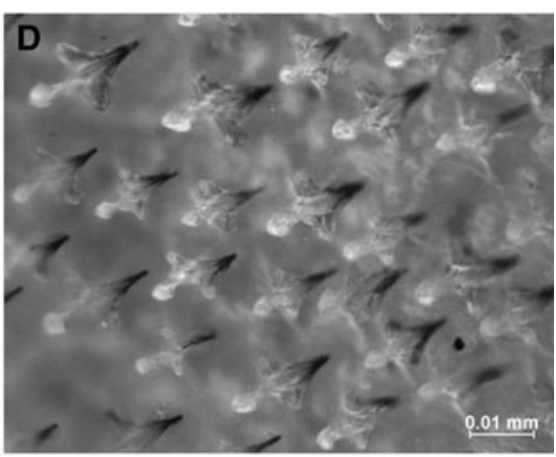

B16-0093_Pectoral fin

Fig. 6. A sample of denticles from two mature males of S. blainville, each of which had both tricuspid and unicuspid denticles; (A) and (C) show the tricuspid denticles from close to the dorsal fin, while (B) and (D) show the unicuspid denticles from just above the pectoral fin.

and S. blainville aggregated within species-specific clusters separated with high statistical support $(B S=100 \%)$ and an average genetic distance of $0.83 \%$, in spite of the high intraspecific diversity that characterizes both species ( 0.42 and $0.28 \%$ respectively).

\section{DISCUSSIDN}

\section{Morphological variability}

\section{DORSAL SPINE TO FIN BASE RATIO}

Serena (2005) differentiates between Squalus blainville and $S$. megalops on the basis of the length of the first dorsal spine in relation to that of the fin base; S. blainville has the first dorsal spine as long as the fin base, whilst $S$. megalops has a first dorsal spine shorter than the fin base. On the other hand, Marouani et al. (2012) state that in S. blainville the length to base ratio is more than 0.5 while in $S$. megalops the ratio is $0.5-0.7$. Either way, on the basis of the length of the first dorsal spine in relation to the fin base, the majority of specimens in the present study would be classified as S. megalops.

However, Bigelow \& Schroeder (1957) already commented that the differences in relative size, and in length at the base of the first, as well as of the second dorsal fins, may not be a reliable enough character to be used for identification or separation between closely related species of Squalus.

\section{DENTICLES}

In general, the dermal denticles on the sides of the trunk may not be as reliable as a number of studies and field guides suggest. In fact, Bigelow \& Schroeder (1957) and Garrick (1960) point out that the dermal denticles of Squalus species do not persist throughout the life of the individual as the scales of bony fishes do, but undergo considerable change with growth of the animal. The closest similarity between the species is in the newly erupted denticles of embryos of $S$. blainville and $S$. megalops, however, as the animals mature, the denticles seem to differ in the shape and length of the anterior prolongation of the median longitudinal ridge; in the adults, the dermal denticles are broad tridentate in S. blainville and simple dagger-shaped in S. acanthias and S. megalops (Garrick, 1960).

Although Garrick (1960) suggests that changes in morphology are largely due to successional replacement of the denticles, the present study clearly shows that the denticles within the same individual vary. The observations made by Garrick (1960) were mostly made on the denticles from the side of the trunk below the first dorsal fin, an area long regarded as 'standard' for sampling the denticles. In this study, the skin samples were obtained from the laterodorsal area, under the first dorsal fin and from just above the pectoral fin. This means that moving from the pectoral fin towards the dorsal fin, the widened denticle sharpens and a simple dagger-shaped denticle or unicuspid is observed.

However, Garrick (1960) does in fact state that the 'standard' area could be misleading in specimens of critical size; those about one-third grown. This is because in such specimens, the denticles are still mostly of juvenile form, except on the side of the caudal peduncle. Similar to what was observed in this study, replacement of denticles on the side of the trunk appears to begin posteriorly and to progressively advance forward. The denticle morphology is a character that 


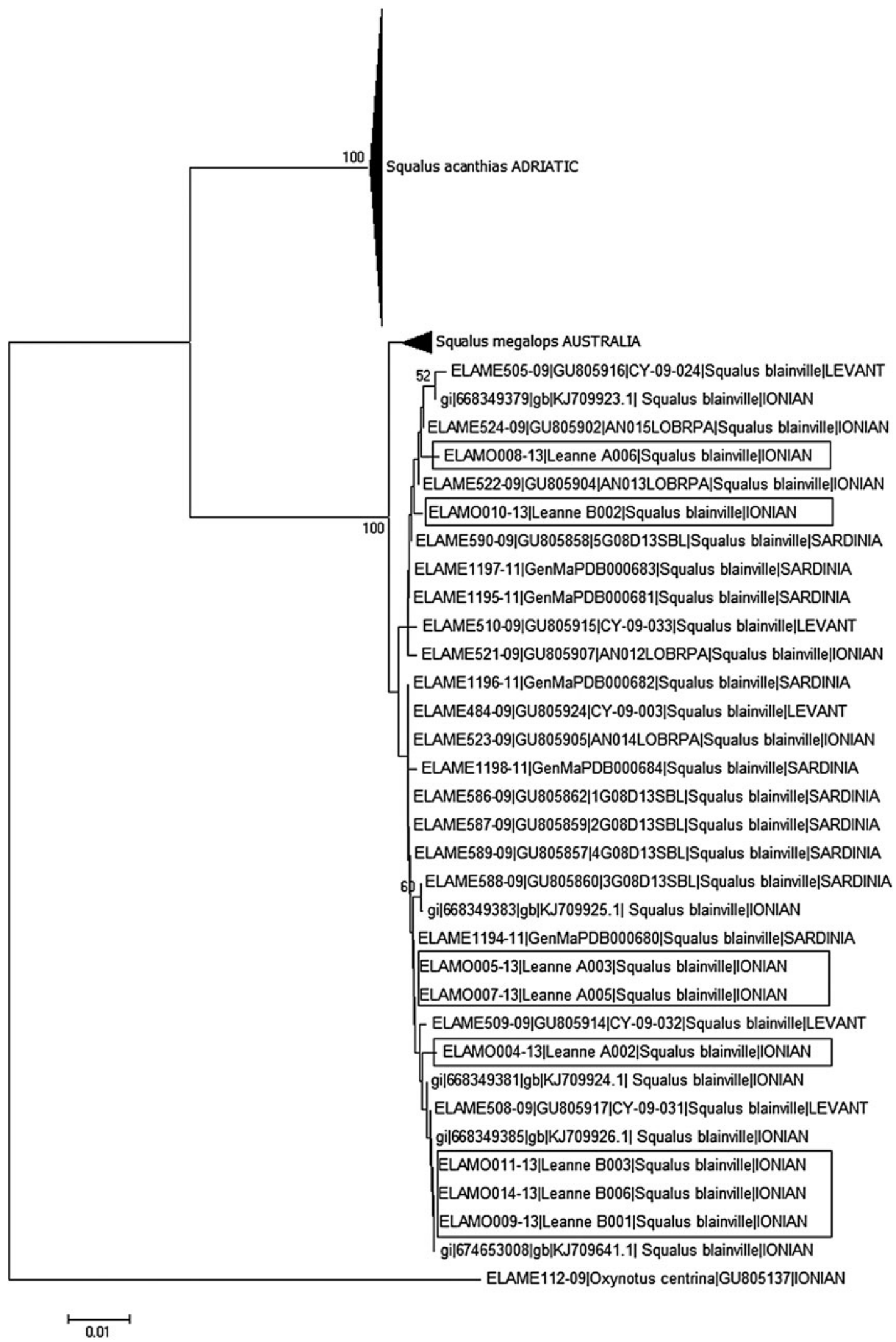

Fig. 7. Neighbour-joining tree based on p-distance model of COI sequences from the three Squalus species. Numbers near nodes are bootstrap (BS) values. Only BS > 50\% are reported. The Maltese Squalus individuals sequenced are shown in boxes. Refer to Supplementary Table A for the list of retrieved sequences of Squalus species from public databases and relative BOLD/NCBI Process ID and FAO Division. 
needs to be interpreted carefully and cannot be used alone for differentiating between S. blainville and S. megalops. For these reasons, a detailed comparison of the denticle morphology of species within the genus Squalus on a worldwide basis, including in the different life stages, is necessary before the denticles can be used as a strong diagnostic character to distinguish between species.

\section{CHONDROCRANIAL MEASUREMENTS}

Most specimens analysed in this study had a double lateral process of the basal plate, which is a character of $S$. megalops, and less than $8 \%$ were characterized by a single lateral process of the basal plate, a character of S. blainville.

In terms of chondrocranial measurements, there were only a few characters which were significantly different; however, there were no consistent sexual or age differences. This shows that the number of lobes and the measurements obtained from the chondrocrania are not a good character to separate the species, since all specimens, whether with one or two processes turned out to be S. blainville.

\section{TEETH}

The teeth in S. blainville are described as being small, compressed and with a single deeply notched cusp, with the outward end strongly oblique, while in S. megalops, the lower teeth are unicuspid, elongated, interlocking and the cusps are directed strongly laterally (Chen et al., 1979; Compagno, 1984; Muñoz-Chápuli \& Ramos, 1989; Ebert \& Stehman, 2013).

From the morphometric analysis of the teeth, including differences in curvatures and edges which may distinguish one species from another, it is clear that there are two clusters when separately analysing the upper and lower teeth from all the specimens considered together. The distinction between these two clusters is not related to sex, maturity or the number of lateral process of the basal plate and neither is it related to whether the lower or upper teeth are analysed, because similar patterns were observed in both cases. This means that from the principal component analysis of the upper or the lower teeth it is factors other than sex, maturity or species identity which give rise to two clearly defined morphological groups of teeth.

\section{GENETIC ANALYSIS}

If only the denticles obtained from the laterodorsal areas under the first dorsal fin are considered, then the specimens analysed in this study would be mostly referred to $S$. megalops. Coupled with the fact that most specimens analysed had a double lateral process of the basal plate, characteristic of $S$. megalops, this would mean that the sample examined consisted of two species. However, the morphological features were not enough to distinguish between the two species because of the overlapping similarities observed in the shape of the denticles and of the teeth, as well as of the discrepancies associated with the number of lateral process of the basal plate. Therefore, morphologically, S. blainville has a range of variability of features that overlaps with that of $S$. megalops and these features include several that are used to distinguish between the species in identification guides. In order to clearly distinguish between the two species, a subsample of specimens was studied genetically to see if molecular data could correspond to the morphological indications.
The genetic analysis pointed out a clear diversification between $S$. acanthias on one hand and $S$. megalops and $S$. blainville on the other $(\mathrm{BS}=100 \%)$. Similarly, in spite of a relevant intra-specific genetic diversity, $S$. megalops and $S$. blainville well differentiate into two separate clusters (Marouani et al., 2012). These results could also correspond to a signal of recent divergence that probably is still ongoing, even if this needs to be supported by further analyses using more molecular markers (i.e. NADH 1, NADH 2, Cytochrome b) for phylogenetic reconstructions in order to enhance the robustness of the topology.

The high level of intraspecific genetic diversity observed in $S$. blainville perfectly matches the intraspecific variability in morphology.

\section{Implications for identification}

This study shows that if identification of specimens is based on morphological characteristics alone, individuals might be misidentified, even if multiple characters based on details of the anatomy, such as skull characteristics and teeth morphology are used. The potential for misidentification is even greater if only field characters are used, such as features associated with the dorsal fin. This suggests that studies or statistical data on S. megalops and S. blainville, where the two may co-occur, may be unreliable due to misidentifications, especially if the identifications were made at sea using field characters. The implications of this for monitoring and management of stocks for fisheries and conservation are obvious.

Based on morphology alone, this study suggests that there are intermediates or other cryptic variation between $S$. megalops and S. blainville in the sample studied; however, genetic analysis of individuals from the extremes of morphological variation shows that only one species, corresponding to $S$. blainville, is present. The implication is that the morphological features which are traditionally used to identify the different species within the genus Squalus may not be reliable and that the range of variation within one species, in this particular case S. blainville, may be large enough to overlap with other species, in this case $S$. megalops. Thus, there is no sure way to identify morphologically ambiguous specimens using field characters, and DNA barcoding may need to be resorted to; generators and users of data on the two species considered here and possibly on other species of Squalus which are morphologically similar, need to be aware of this.

\section{SUPPLEMENTARY MATERIAL}

To view supplementary material for this article, please visit http://dx.doi.org/10.1017/Soo25315415001915.

\section{ACKNOWLEDGEMENTS}

We thank the Department of Fisheries and Aquaculture within the Ministry for Sustainable Development, the Environment and Climate Change (MSDEC) of the Government of Malta for making the specimens of Squalus available for study. 


\section{FINANCIAL SUPPDRT}

$\mathrm{AF}$ and $\mathrm{AC}$ were supported by funds from the University of Bologna and JJB, LB and PJS were supported by funds from the University of Malta Research Committee, for which we are grateful.

\section{REFERENCES}

Abiadh A., Chetoui M., Lamine-Cheniti T., Capanna E. and Colangelo P. (2010) Molecular phylogenetics of the genus Gerbillus (Rodentia, Gerbillinae): implications for systematics, taxonomy and chromosomal evolution. Molecular Phylogenetics and Evolution 56, 513-518.

Bigelow H.B. and Schroeder W.C. (1957) A study of the sharks of the suborder Squaloidea. Bulletin of the Museum of Comparative Zoology 117, 1-150.

Bookstein F.L. (1997) Landmark methods for forms without landmarks: morphometrics of group differences in outline shape. Medical Image Analysis 1, 225-243.

Bradai M., Saidi B. and Enajjar S. (2012) Elasmobranchs of the Mediterranean and Black Sea: status, ecology and biology. General Fisheries Commission for the Mediterranean (GFCM) Studies and Reviews, No. 91. Rome: Food and Agriculture Organization of the United Nations, p. 103.

Chen C., Taniuchi T. and Nose Y. (1979) Blainville's dogfish, Squalus blainville, from Japan, with notes on S. mitsukurii and S. japonicus. Japanese Journal of Ichthyology 26, 26-42.

Compagno L.J.V. (1984) Squaliformes - Dogfish sharks. In Fischer W. and Nauen C. (eds) FAO Species Catalogue. Volume 4. Sharks of the World. An annotated and illustrated catalogue of shark species known to date. Part 1 - Hexanchiformes to Lamniformes. Rome: FAO Fish Synopses, p. 249.

Doyle J.J. and Doyle J.L. (1987) A rapid DNA isolation procedure for small quantities of fresh leaf tissue. Phytochemistry Bulletin 19, 11-15.

Ebert D.A. and Stehman M.F. (2013) Sharks, batoids, and chimaeras of the North Atlantic. FAO Species Catalogue for Fishery Purposes 7 (Rome). Rome: Food and Agriculture Organization of the United Nations, pp. 56-66.

Ebert D.A., White W.T., Goldman K.J., Compagno L.J.V., Engel T.S.D. and Ward R.D. (2010) Resurrection and redescription of Squalus suckleyi (Girard, 1854) from the North Pacific, with comments on the Squalus acanthias subgroup (Squaliformes: Squalidae). Zootaxa $40,22-40$.

FAO (2015) Fisheries and Aquaculture Department. Aquatic Species Fact Sheets. http://www.fao.org/fishery/species/search/en.

Farré M., Tuset V.M., Maynou F., Recasens L. and Lombarte A. (2013) Geometric morphology as an alternative for measuring the diversity of fish assemblages. Ecological Indicators 29, 159-166.

Felsenstein J. (1985) Confidence limits on phylogenies: an approach using the bootstrap. Evolution 39, 783-791.

Ferdous S. and Armbruster J.W. (2012) ACSI II Guide to Geometric Morphometrics in MorphoJ. Department of Biological Sciences, Auburn University, Auburn, AL, 35 pp. http://www.auburn.edu/ armbrjw/gmguide.pdf.

Fisheries Control Directorate (2013) Fisheries management plan. http:// stecf.jrc.ec.europa.eu/documents/43805/595618/Maltas+Fisheries+ Management+Plan+-+Trawler+and+Lamapra.pdf.

Garrick J.A.F. (1960) Studies on New Zealand Elasmobranchii. Part XII The species of Squalus from New Zealand and Australia; and a general account and key to the New Zealand Squalidae. Transactions of the Royal Society of New Zealand 88, 519-557.

Garrick J.A.F. (1961) A note on the spelling of the specific name of the immaculate spiny dogfish, Squalus blainvillei (Risso 1826). Transactions of the Royal Society of New Zealand 88, 843 .

Hildebrand M. (1968) Anatomical preparations. Berkeley, CA: University of California Press.

Kendall D.G. (1977) The diffusion of shape author. Advances in Applied Probability 9, 428-430.

Klingenberg C.P. (2011) MorphoJ: an integrated software package for geometric morphometrics. Molecular Ecology Resources 11, 353-357.

Knudsen J.W. (1966) Biological techniques; collecting, preserving, and illustrating plants and animals. New York, NY: Harper \& Row.

Landi M., Dimech M., Arculeo M., Biondo G., Martins R., Carneiro M., Carvhalho G.R., Lo Brutto S. and Costa F.O. (2014) DNA barcoding for species assignment: the case of Mediterranean marine fishes. PLoS ONE 9, e106135. 5.

Last P., White W., Pogonosk J., Gledhill D., Yearsley G., Ward R. and Pogonosk J. (2007) Part 1 - Application of a rapid taxonomic approach to the genus Squalus. In Last P., White W. and Pogonoski J. (eds) Descriptions of new dogfishes of the genus Squalus (Squaloidea-Squalidae). Aspendale: CSIRO Marine and Atmospheric Research, pp. 1-9.

Lo Brutto S., Curatolo T., Calvaruso C. and Galil B.S. (2013) Geometric morphometry supports a taxonomic revision of the Mediterranean Bathyporeia guilliamsoniana (Spence Bate, 1857) (Amphipoda, Bathyporeiidae). Crustaceana 86, 820-828.

Marouani S., Chaâba R., Kadri H., Saidi B., Bouain A., Maltagliati F., Last P., Séret B. and Nejmeddine Bradai M. (2012) Taxonomic research on Squalus megalops (Macleay, 1881) and Squalus blainvillei (Risso, 1827) (Chondrichthyes: Squalidae) in Tunisian waters (central Mediterranean Sea). Scientia Marina 76, 97-109.

MEDITS (2013) International bottom trawl survey in the Mediterranean. Instruction manual Version 7. MEDITS Working Group, $120 \mathrm{pp}$. http:// www.sibm.it/MEDITS\%202011/docs/Medits_Handbook_2013_version_ 7_25092013.pdf.

Muñoz-Chápuli R. and Ramos F. (1989) Morphological comparison of Squalus blainvillei and S. megalops in the Eastern Atlantic, with notes on the genus. Japanese Journal of Ichthyology 36, 6-21.

Nieto A., Ralph G.M., Comeros-Raynal M.T., Kemp J., García Criado M., Allen D.J., Dulvy N.K., Walls R.H.L., Russell B., Pollard D., García S., Craig M., Collette B.B., Pollom R., Biscoito M., Labbish Chao N., Abella A., Afonso P., Álvarez H., Carpenter K.E., Clò S., Cook R., Costa M.J., Delgado J., Dureuil M., Ellis J.R., Farrell E.D., Fernandes P., Florin A-B., Fordham S., Fowler S., Gil de Sola L., Gil Herrera J., Goodpaster A., Harvey M., Heessen H., Herler J., Jung A., Karmovskaya E., Keskin C., Knudsen S.W., Kobyliansky S., Kovačić M., Lawson J.M., Lorance P., McCully Phillips S., Munroe T., Nedreaas K., Nielsen J., Papaconstantinou C., Polidoro B., Pollock C.M., Rijnsdorp A.D., Sayer C., Scott J., Serena F., Smith-Vaniz W.F., Soldo A., Stump E. and Williams J.T. (2015) European red list of marine fishes. Luxembourg: Publications Office of the European Union. 84 pp. doi: $10.2779 / 082723$.

Ragonese S., Vitale S., Dimech M. and Mazzola S. (2013) Abundances of demersal sharks and chimaera from 1994-2009 scientific surveys in the central Mediterranean Sea. PLoS ONE 8, e74865.

Saitou N. and Nei M. (1987) The neighbor-joining method: a new method for reconstructing phylogenetic trees. Molecular Biology and Evolution 4, 406-425. 
Serena F. (2005) FAO Species identification guide for Fishery Purposes. Field identification guide to the sharks and rays of the Mediterranean and Black Sea. Rome: Food and Agriculture Organization of the United Nations, $124 \mathrm{pp}$

Song H., Buhay J.E., Whiting M.F. and Crandall K.A. (2008) Many species in one: DNA barcoding overestimates the number of species when nuclear mitochondrial pseudogenes are coamplified. Proceedings of the National Academy of Sciences USA 105, 1348613491.

Tamura K., Stecher G., Peterson D., Filipski A. and Kumar S. (2013) MEGA6: Molecular Evolutionary Genetics Analysis Version 6.0. Molecular Biology and Evolution 30, 2725-2729.

Thompson J.D., Higgins D.G. and Gibson T.J. (1994) CLUSTAL W: improving the sensitivity of progressive multiple sequence alignment through sequence weighting, position-specific gap penalties and weight matrix choice. Nucleic Acids Research 22, 4673-4680.

Ward R.D., Holmes B.H., Zemlak T.S. and Smith P.J. (2007) Part 12 DNA barcoding discriminates spurdogs of the genus Squalus. In Last P., White W. and Pogonoski J. (eds) Descriptions of new dogfishes of the genus Squalus (Squaloidea-Squalidae). Aspendale: CSIRO Marine and Atmospheric Research, pp. 117-130.

Ward R.D., Zemlak T.S., Innes B.H., Last P.R. and Hebert P.D.N. (2005) DNA barcoding Australia's fish species. Philosophical Transactions of the Royal Society Biological Sciences 360, 1847-1857.

and

White W., Yearsley G. and Last P. (2007) Part 11 - Clarification of the status of Squalus tasmaniensis and a diagnosis of Squalus acanthias from Australia, including a key to the Indo-Australasian species of Squalus. In Last P., White W. and Pogonoski J. (eds) Descriptions of new dogfishes of the genus Squalus (Squaloidea-Squalidae). Aspendale: CSIRO Marine and Atmospheric Research, pp. 109-115.

\section{Correspondence should be addressed to:}

J.J. Bonello

Department of Biology, University of Malta, Msida MSD2080, Malta

email: juanjbonello@gmail.com 